\title{
The Impact of Corporate News Announcement on Insider Trading: Evidence from the Stock Exchange of Thailand
}

Nareerat Taechapiroontong and Chayanit Laoniramai

\begin{abstract}
The purpose of this study is to examine insider trading behavior reaction to news announcement by using firms listed on the Stock Exchange of Thailand (SET). The results show that the information content are significant to insider buys but not to insider sells. In other words, only insider buys are associated with abnormal returns. However, corporate news disclosures greatly impact insider sells. Trading before good news announcement shows significant abnormal return for both sells and buys, specifically, insider buys prior to good news significantly impact on stock prices.
\end{abstract}

Keywords - insider trading, event study, abnormal return, Thailand

\section{Introduction}

The behavior of insider trading has attracted a great attention from various market participants such as researchers, policy-makers, and investors. Insiders, in this study, refer to corporate insiders and large shareholders. It is due to most insiders would have ability to time the market. They usually trade their own securities in favorable time and earn abnormal returns. Moreover, insiders who possess non-public information about their firms may be motivated to take advantage of it through their trading, but such action is prohibited by law.

Prior studies have documented that insiders are able to outperform the market. In other words, they can gain abnormal returns through trading of their own stocks (e.g. Jaffe, 1974; Seyhun, 1986; and Lakonishok and Lee, 2001). We choose to examine insider trading in Thailand because most studies about insider trading are based on U.S. market, and these results may not be robust in Asian or emerging markets.

To place investors on a more equal basis, the Securities and Exchange Commission (SEC) issues rules to provide full and fair information disclosure about firms including to announce significant investors' trading shares in security markets to the public. Although SEC's regulations specifically prohibit trading on the private information, there is evidence about the extraordinary stock price of firm at which the public of specific-news announcement.

Nareerat Taechapiroontong, Chayanit The Impact of Corporate News Announcement on Insider Trading: Evidence from the Stock Exchange of Thailand Laoniramai University Name

College of Management Mahidol University
Thailand

For example in Thaicom Pcl., when Thailand's government announced plans to buy stocks back from Singapore's state-owned investment company, Thaicom's stocks rose by its daily 30 percent limit in Bangkok trading. In the same day, the benchmark the Stock Exchange of Thailand (SET) Index increased only $1.5 \%$ (www.businessweek.com, June 14, 2010). We set up two objectives of the study.

1) To investigate insiders' trading activities and market reaction.

2) To examine the relationship between insiders' trading activities and subsequent corporate news announcement.

\section{Literature Review}

The earlier research of insiders focused on the performance of insider trading activities. Most studies measured abnormal returns during a period of insider trading. Jaffe (1974) and Seyhun (1986) assert that insider trades are profitable. There are significant abnormal returns to insider over 6 to 12 months after the transaction. More recent researches report a similar result. Insiders gain more profits than average from their transactions (Lakonishok and Lee, 2001; Fidrmuc et al., 2006; and Betzer and Theissen, 2009). These imply that insider trading are informative.

The news announcement provide information to market participants. Prior knowledge of information will affect prices when it is publicly released. This allows informed investors who know private information, tend to engage in a profitable trading strategy. Many previous researches have studied insider trading around certain public events. To illustrate, Keown and Pinkerton (1981) and Jabbour et al. (2000) find information leakage before merger and acquisition announcements. For earnings announcements, Huddart et al. (2007) report that insider trades are larger after earnings disclosures and become a profitable manner; sell (buy) stocks following good (bad) announcements. In a study by Givoly and Palmon (1985), they find no significant relationship between timing of insider trading and combined news announcements. However, the findings of Noe (1999) and Cheng and Lo (2006) indicate that insider transactions are related to voluntary disclosures in the sense that they can take benefits from disclosure policies. 


\section{Data and Methodology}

The data source of insider trading are the SEC's Form 59-2 and Form 246-2. The two-form reports contain all transactions by insiders. They are daily provided through the SEC's website. The study period covers from January 2000 to December 2008. The data of securities market and companyspecific information such as market index, stock price, market capitalization, are obtained from SETSMART. News reports on individual companies are also from SETSMART. This database is a main source of financial data provided by SET.

We investigate buys and sells of common shares of listed firms on the SET. Only complete and meaningful transactions are included in our sample. We restrict the transactions that have trading volume for the analysis period. Following these adjustments, the number of observations reduces by $39 \%$ and total sample remains 29,752 transactions from 490 firms. The transactions relate to corporate insiders and large shareholders representing 27,179 trades and 2,573 trades, respectively.

Table I shows the breakdown of insider trading sample by year. The number of firms which has insider trading has been increasing every year. Also, the total number of transactions tends to increase.

\section{A. News Classifications}

This study uses all significant events relating to companies where are reported in SETSMART's database. We assume that these kinds of news are all important and will affect on share prices. We employ the broad classification of news into good or bad according to the market's reaction to the news story (Koppel and Shtrimberg, 2004). We find the different value in price change of stock from the closing price on the day before the publication of news to the opening price on the day after the news. We define good news if the price change of stock is positive and bad news if the price change of stock is negative. We expect neutral news to produce no price change reaction.

To examine the relationship of insider trading activities and subsequent corporate news, we consider only the first news publication following insider transactions (Givoly and Palmon, 1985). Although the first publication of news might not have motivated insider trading, insiders would trade in such a way for their profits; expect a positive relation between the trade direction and the content of the first news, if they do exploit inside information on specific forthcoming disclosures.

TABLE I.

DISTRIBUTION OF INSIDER TRANSACTION SAMPLE GROUPED BY YEAR

\begin{tabular}{|c|c|c|c|c|c|c|c|c|c|c|}
\hline & 2000 & 2001 & 2002 & 2003 & 2004 & 2005 & 2006 & 2007 & 2008 & All firms \\
\hline Number of firms & 65 & 131 & 172 & 239 & 226 & 245 & 272 & 280 & 323 & 490 \\
\hline \multicolumn{11}{|l|}{ Number of transactions } \\
\hline Buy & 940 & 1,007 & 1,153 & 1,242 & 1,737 & 1,970 & 1,547 & 1,848 & 3,422 & 14,866 \\
\hline Sell & 516 & 890 & 1,385 & 2,387 & 1,412 & 2,026 & 2,434 & 2,314 & 1,522 & 14,886 \\
\hline $\begin{array}{c}\text { All } \\
\text { Average number of } \\
\text { transactions per firm }\end{array}$ & 1,456 & 1,897 & 2,538 & 3,629 & 3,149 & 3,996 & 3,981 & 4,162 & 4,944 & 29,752 \\
\hline Buy & 14 & 8 & 7 & 5 & 8 & 8 & 6 & 7 & 11 & 30 \\
\hline Sell & 8 & 7 & 8 & 10 & 6 & 8 & 9 & 8 & 5 & 30 \\
\hline $\begin{array}{l}\text { All } \\
\text { Total number of share } \\
\text { traded (million shares }\end{array}$ & 22 & 15 & 15 & 15 & 14 & 16 & 15 & 15 & 16 & 60 \\
\hline Buy & 50 & 114 & 3,323 & 2,145 & 2,139 & 4,229 & 5,755 & 16,439 & 29,255 & 63,449 \\
\hline Sell & 37 & 119 & 985 & 8,187 & 10,064 & 8,684 & 17,760 & 19,680 & 30,680 & 96,196 \\
\hline $\begin{array}{l}\text { All } \\
\text { Total value of shares } \\
\text { traded (million baht) }\end{array}$ & 87 & 233 & 4,308 & 10,332 & 12,203 & 12,913 & 23,514 & 36,119 & 59,934 & 159,644 \\
\hline Buy & 3,004 & 1,900 & 20,400 & 55,043 & 26,593 & 47,480 & 141,297 & 150,856 & 63,113 & 509,687 \\
\hline Sell & 1,606 & 2,464 & 20,241 & 161,743 & 101,655 & 122,564 & 353,718 & 206,110 & 133,835 & $1,103,936$ \\
\hline All & 4,610 & 4,363 & 40,641 & 216,785 & 128,248 & 170,045 & 495,016 & 356,966 & 196,948 & $1,613,623$ \\
\hline
\end{tabular}


Proc. of The Seventh Intl. Conf. on Advances in Social Science, Management and Human Behaviour - SMHB 2018. Copyright (C) Institute of Research Engineers and Doctors, USA. All rights reserved.

ISBN: 978-1-63248-160-3 doi: 10.15224/978-1-63248-160-3-23

TABLE II. PERCENTAGE CAAR FOR INSIDER TRADING EVENTS

\begin{tabular}{|c|c|c|c|c|c|c|c|c|c|}
\hline \multirow{2}{*}{ Event window } & \multicolumn{3}{|c|}{ All types of insider } & \multicolumn{3}{|c|}{ Corporate insider } & \multicolumn{3}{|c|}{ Large shareholder } \\
\hline & All trades & Buy & Sell & All trades & Buy & Sell & All trades & Buy & Sell \\
\hline$(-30,-1)$ & 4.3313 **** & $1.1899 * * *$ & $\begin{array}{l}7.6394 \\
* * *\end{array}$ & $\begin{array}{l}4.2650 \\
* * *\end{array}$ & $0.9575 * * *$ & $\begin{array}{l}8.0484 \\
\text { **** }\end{array}$ & 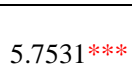 & $6.2264 * * *$ & 5.4658 *** \\
\hline & $(0.0000)$ & $(0.0000)$ & $(0.0000)$ & $(0.0000)$ & $(0.0000)$ & $(0.0000)$ & $(0.0000)$ & $(0.0000)$ & $(0.0000)$ \\
\hline$(-20,-1)$ & $\begin{array}{l}3.1024 \\
(0.0000) \\
\text { **** }\end{array}$ & $\begin{array}{l}0.5919 \\
(0.0000) \\
* * *\end{array}$ & $\begin{array}{l}5.8364 \\
(0.0000) \\
\text { *** }\end{array}$ & $\begin{array}{l}3.0486 \\
(0.0000) \\
* * *\end{array}$ & $\begin{array}{l}0.3543 \\
(0.0096) \\
* * *\end{array}$ & $\begin{array}{l}6.2111 \\
(0.0000) \\
* * *\end{array}$ & $\begin{array}{l}4.2673 \\
(0.0000) \\
\text { *** }\end{array}$ & $\begin{array}{l}5.2256 \\
(0.0000) \\
* * *\end{array}$ & $\begin{array}{l}3.8253 \\
(0.0000) \\
* * *\end{array}$ \\
\hline$(-10,-1)$ & $\begin{array}{l}1.7962 \\
(0.0000) \\
\text { **** }\end{array}$ & $\begin{array}{l}0.0137 \\
(0.8880)\end{array}$ & $\begin{array}{l}3.7378 \\
(0.0000) \\
\text { *** }\end{array}$ & $\begin{array}{l}1.7928 \\
(0.0000) \\
\text { **** }\end{array}$ & $\begin{array}{l}-0.1539 \\
(0.1152)\end{array}$ & $\begin{array}{l}4.0780 \\
(0.0000) \\
* * *\end{array}$ & $\begin{array}{l}2.2911 \\
(0.0000) \\
\text { *** }\end{array}$ & $\begin{array}{l}3.2436 \\
(0.0000) \\
* * *\end{array}$ & $\begin{array}{l}1.8517 \\
(0.0001) \\
\text { *** }\end{array}$ \\
\hline$(-5,-1)$ & $\begin{array}{l}1.0424 \\
(0.0000) \\
* * *\end{array}$ & $\begin{array}{l}-0.1821 \\
(0.0090) \\
\text { *** }\end{array}$ & $\begin{array}{l}2.3761 \\
(0.0000) \\
* * *\end{array}$ & $\begin{array}{l}1.0467 \\
(0.0000) \\
* * *\end{array}$ & $\begin{array}{l}-0.3137 \\
(0.0000) \\
\text { *** }\end{array}$ & $\begin{array}{l}2.6436 \\
(0.0000) \\
* * *\end{array}$ & $\begin{array}{l}1.3919 \\
(0.0000) \\
* * *\end{array}$ & $\begin{array}{l}2.2578 \\
(0.0000) \\
* * *\end{array}$ & $\begin{array}{l}0.9925 \\
(0.0055) \\
* * *\end{array}$ \\
\hline Transaction day & $\begin{array}{l}0.4118 \\
(0.0000)\end{array}$ & $\begin{array}{l}-0.1948 \\
(0.0000)\end{array}$ & $\begin{array}{l}1.0728 \\
(0.0000)\end{array}$ & $\begin{array}{l}0.4281 \\
(0.0000)\end{array}$ & $\begin{array}{l}-0.2875 \\
(0.0000)\end{array}$ & $\begin{array}{l}1.2684 \\
(0.0000)\end{array}$ & $\begin{array}{l}0.3579 \\
(0.0074)\end{array}$ & $\begin{array}{l}1.2046 \\
(0.0000)\end{array}$ & -0.0336 \\
\hline$(0)$ & 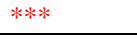 & **** & **** & **** & **** & **** & **** & **** & $(0.8451)$ \\
\hline$(+1,+5)$ & $\begin{array}{l}0.5110 \\
(0.0000) \\
\text { *** }\end{array}$ & $\begin{array}{l}0.8177 \\
(0.0000) \\
\text { *** }\end{array}$ & $\begin{array}{l}0.1766 \\
(0.0195) \\
* *\end{array}$ & $\begin{array}{l}0.5113 \\
(0.0000) \\
* * *\end{array}$ & $\begin{array}{l}0.7474 \\
(0.0000) \\
* * *\end{array}$ & $\begin{array}{l}0.2339 \\
(0.0021) \\
* * *\end{array}$ & $\begin{array}{l}0.5679 \\
(0.0115) \\
* *\end{array}$ & $\begin{array}{l}1.9779 \\
(0.0000) \\
* * *\end{array}$ & $\begin{array}{l}-0.0840 \\
(0.7563)\end{array}$ \\
\hline$(+1,+10)$ & $\begin{array}{l}0.9201 \\
(0.0000) \\
\text { **** }\end{array}$ & $\begin{array}{l}1.2680 \\
(0.0000) \\
* * *\end{array}$ & $\begin{array}{l}0.5407 \\
(0.0000) \\
\text { *** }\end{array}$ & $\begin{array}{l}0.9064 \\
(0.0000) \\
\text { *** }\end{array}$ & $\begin{array}{l}1.1919 \\
(0.0000) \\
\text { *** }\end{array}$ & $\begin{array}{l}0.5707 \\
(0.0000) \\
\text { **** }\end{array}$ & $\begin{array}{l}1.1513 \\
(0.0001) \\
\text { *** }\end{array}$ & $\begin{array}{l}2.4913 \\
(0.0000) \\
\text { *** }\end{array}$ & $\begin{array}{l}0.5317 \\
(0.1324)\end{array}$ \\
\hline$(+1,+20)$ & $\begin{array}{l}1.7549 \\
(0.0000) \\
* * *\end{array}$ & $\begin{array}{l}2.2100 \\
(0.0000) \\
* * *\end{array}$ & $\begin{array}{l}1.2583 \\
(0.0000) \\
* * *\end{array}$ & $\begin{array}{l}1.7402 \\
(0.0000) \\
* * *\end{array}$ & $\begin{array}{l}2.1252 \\
(0.0000) \\
* * *\end{array}$ & $\begin{array}{l}1.2875 \\
(0.0000) \\
* * *\end{array}$ & $\begin{array}{l}1.7718 \\
(0.0000) \\
\text { *** }\end{array}$ & $\begin{array}{l}3.0707 \\
(0.0000) \\
* * *\end{array}$ & $\begin{array}{l}1.1713 \\
(0.0168) \\
\text { ** }\end{array}$ \\
\hline$(+1,+30)$ & $\begin{array}{l}2.3591 \\
(0.0000) \\
\text { **** }\end{array}$ & $\begin{array}{l}2.8610 \\
(0.0000) \\
\text { *** }\end{array}$ & $\begin{array}{l}1.8112 \\
(0.0000) \\
\text { **** }\end{array}$ & $\begin{array}{l}2.3642 \\
(0.0000) \\
\text { **** }\end{array}$ & $\begin{array}{l}2.7769 \\
(0.0000) \\
\text { *** }\end{array}$ & $\begin{array}{l}1.8787 \\
(0.0000) \\
* * *\end{array}$ & $\begin{array}{l}2.0889 \\
(0.0000) \\
* * *\end{array}$ & $\begin{array}{l}3.6640 \\
(0.0001) \\
* * *\end{array}$ & $\begin{array}{l}1.3607 \\
(0.0191) \\
* *\end{array}$ \\
\hline Sample size & 29,752 & 14,866 & 14,886 & 27,179 & 14,035 & 13,144 & 2,573 & 831 & 1,742 \\
\hline
\end{tabular}

In each row, the first number shows the CAAR and the second in parentheses shows test statistic $(p$-value). $*, * *$ and $* * *$ denote statistical significance at the $10 \%, 5 \%$ and $1 \%$ level respectively.

\section{B. Event Study Methodology}

To assess the impact on share prices of insider trades, we use a standard event study methodology. We first compute daily returns for each security by taking the difference of market capitalization between the end and the beginning of period divided by market capitalization at the beginning period. We apply the market capitalization instead of price in order to avoid stock splits' problem. Moreover, we adjust dividend in stock return. The percentage of stock return is calculated by the equation below:

$$
\text { Rit }=\left[\frac{(\text { MCit }- \text { MCit }-1)}{M C i t-1}+\text { DYit }\right] \times 100
$$

Where Rit is the daily return of stock $i$ on day $t$. MCit and MCit- 1 are the market capitalization of stock $i$ at the end of day $t$ and $t-1$. DYit is dividend yield of stock $i$ on day $t$.

In this paper, we follow an event study procedure of Brown and Warner (1985) by using market-adjusted returns to compute the abnormal return. Our benchmark return is SET index return. We perform the separation of event study for insider buys and sells. The number of net insider transactions for each firm in a day is used to classify the direction of insider. If the number of insider busy is higher than the number of insider sells, we classify as a buying firm for that day. The convert situation is as a selling firm. We exclude the day that the number of insider buys equals the number of insider sells. For the event window, we choose a period of 30 days after insider trading day because it reflects the complete market reaction to insider trade. Abnormal returns equation is following:

$$
\text { ARit }=\text { Rit }- \text { Rmt }
$$

where ARit is the abnormal return of stock $i$ on day $t$. Rit and $R m t$ are return of stock $i$ and SET index on day $t$. Then we calculate the average abnormal return (AAR) and the cumulative average abnormal return (CAAR). Where $N$ is the number of firms with insider trading on day $t$.

$$
\begin{aligned}
& \text { AARt }=\frac{1}{N} \sum_{i=1}^{N} A R i t \\
& C A A R(t 1, t 2)=\sum_{t=t 1}^{t 2} A A R t
\end{aligned}
$$

The null hypothesis is to test whether the CAAR is equal to zero. The test statistic is based on Barber and Lyon (1997). 
Proc. of The Seventh Intl. Conf. on Advances in Social Science, Management and Human Behaviour - SMHB 2018. Copyright ( $)$ Institute of Research Engineers and Doctors, USA. All rights reserved.

ISBN: 978-1-63248-160-3 doi: 10.15224/978-1-63248-160-3-23

Where $\sigma(\operatorname{CAR}(t 1, t 2))$ is the cross-sectional sample standard deviation of the cumulative abnormal returns for the sample of $n$ firms between $t 1$ and $t 2$ period.

$$
t C A A R=\frac{C A A R(t 1, t 2)}{\sigma(C A R(t 1, t 2)) \sqrt{n}}
$$

\section{Empirical Results}

This section reports two main results according to our hypotheses. We show three groups of insiders which are all types of insider, corporate insider, and large shareholder. The buy and sell activities are separately presented.

\section{A. Market Reaction to Insiders Trades}

Hla: The relation of cumulative average abnormal return (CAAR) to the insiders' buy is positive.

The result in Table II supports H1a. The market reaction to insiders' buy is positive. For example, when all types of insider buys, the CAAR1,30 is increasing to $2.86 \%$. Similar results are in corporate insider and large shareholder that the CAAR amounts to $2.77 \%$ and $3.66 \%$, respectively. These values are significantly different from zero when considering the $\mathrm{p}$-value. This suggests that insiders can time their buys and make abnormal profits.

HIb: The relation of cumulative average abnormal return (CAAR) to the insiders' sell is negative.

For the result in Table II, the market reaction to insiders' sell is not negative. Even though most post-event CAARs are significantly different from zero, they are positive. The CAAR1,30 for each group of insider are $1.81 \%$ to all types of insider, $1.87 \%$ to corporate insider, and $1.36 \%$ to large shareholder. Hence, we must reject the hypothesis H1b. This indicates that insiders cannot time their sell to get abnormal profits.

Our result is consistent with previous research only for insider buy. Most studies state that insider trades either buy or sell are profitable (Jaffe, 1974; Seyhun, 1986; and Lakonishok and Lee, 2001). In this paper, the evidence shows that insiders can time their buys. They do perform well and get abnormal returns. In contrast, insiders cannot time their sell. They fail to get abnormal returns. Despite selling shares after price run-up, insiders did not sell at the highest price. The possible explanation is that the primary reason for insider buy is to make profits but there exist many reasons for insider sell such as liquidity needs or portfolio diversification.

The graph in Figure 1 shows the percentage cumulative average abnormal returns (CAAR) of insider trading from 30 days before to 30 days after the insider trading date. The transactions are separated into buy (black line) and sell (red line).

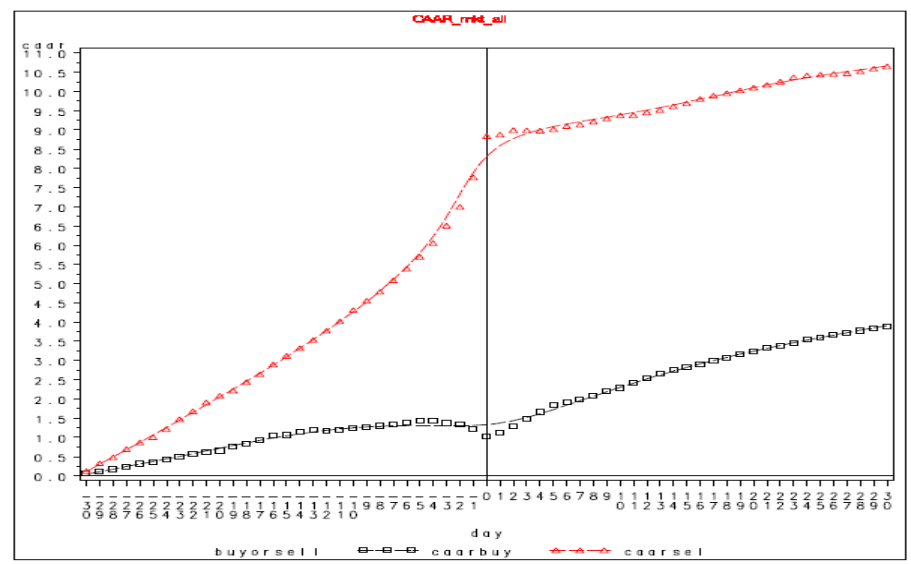

Figure 1a. All types of insider

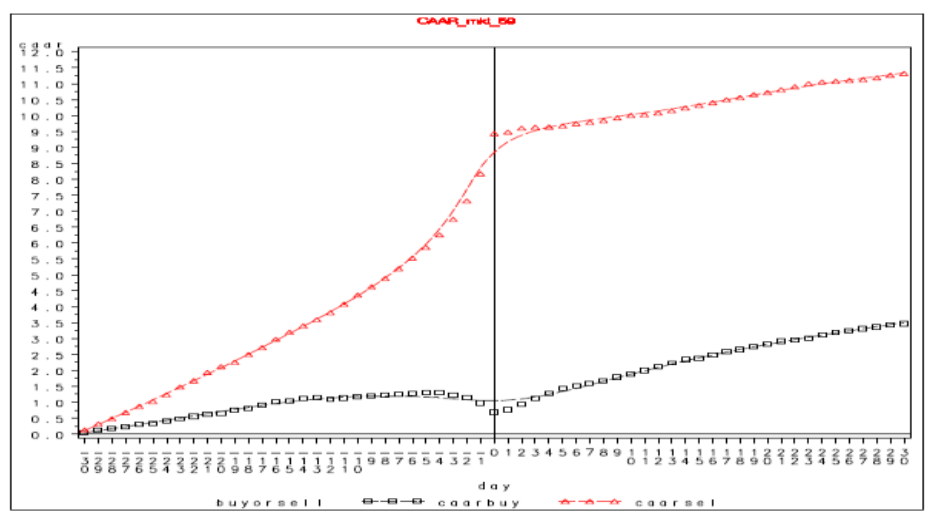

Figure 1b. Corporate insider

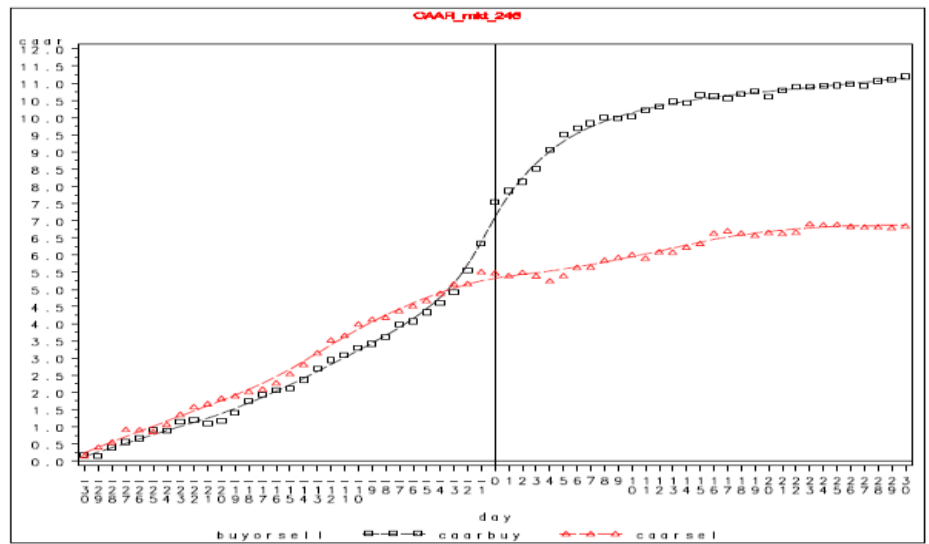

Figure 1c. Large shareholder

\section{B. Relationship between Insider Trades and Subsequent Corporate News Announcement}

H2a: The abnormal returns are associated with the first subsequent news. Insiders' buy and sell shares before news announcement gain large abnormal returns. Under $\mathrm{H} 2 \mathrm{a}$, we test whether insider trades before news announcement earn most abnormal returns. On buy side, most post-event CAARs 
Proc. of The Seventh Intl. Conf. on Advances in Social Science, Management and Human Behaviour - SMHB 2018. Copyright $\odot$ Institute of Research Engineers and Doctors, USA. All rights reserved.

ISBN: 978-1-63248-160-3 doi: 10.15224/978-1-63248-160-3-23

of both with news and no news are significantly positive but there are no significant differences in news group. These indicate that insider buy followed by news or no-news does not provide different impact on abnormal returns. On sell side, all types of insider and corporate insider, the CAAR1, 30 of news is significant and higher than no news. The statistics result are not presented here due to limited space. Figure 2 show event day relative to insider trading by the first subsequent news. The graph shows the percentage cumulative average abnormal returns (CAAR) of insider trading during 30

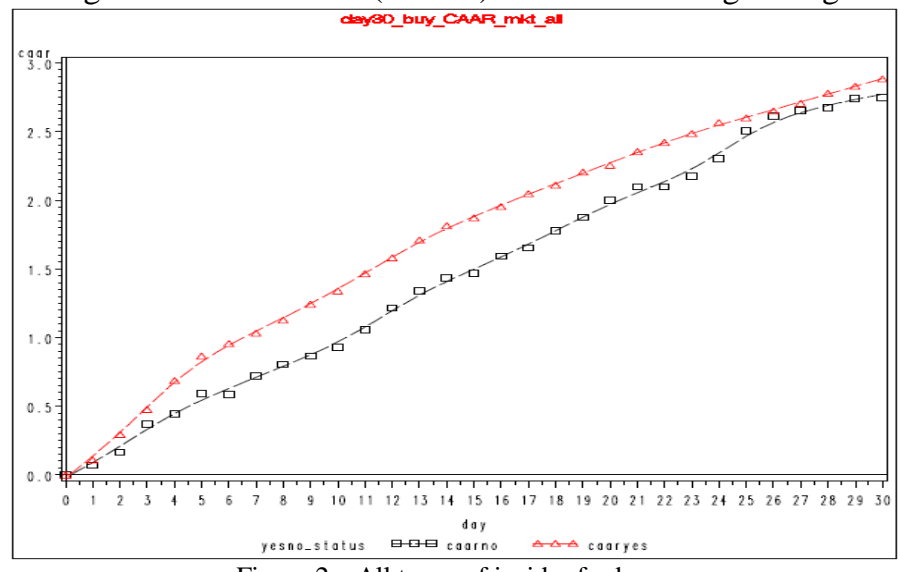

Figure 2a. All types of insider for buy

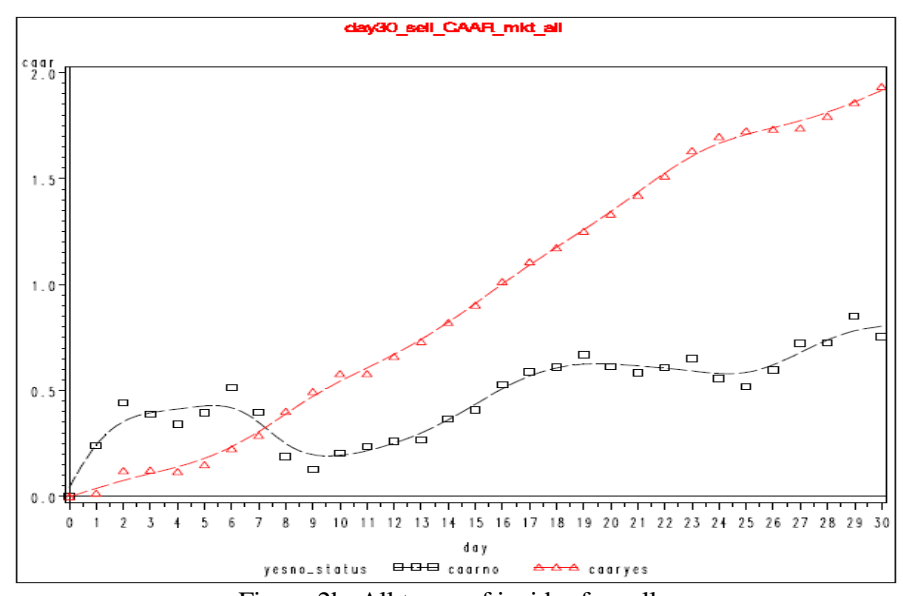

Figure 2b. All types of insider for sell

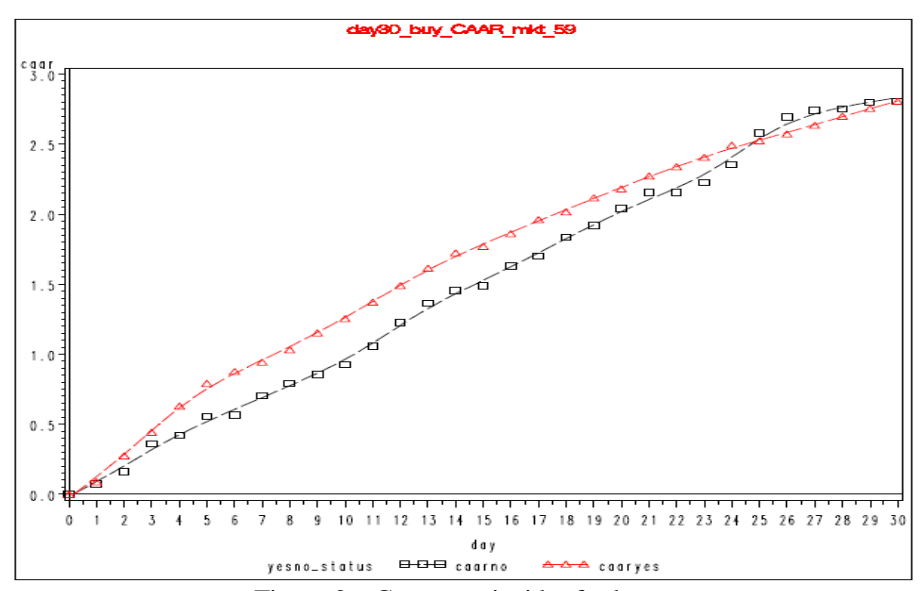

Figure 2c. Corporate insider for buy days after the transaction date. They are separated by withnews (red line) and no-news (black line).

In sum, only sell of all insider and corporate insider before news get high abnormal returns. The study of Noe (1999) also finds that managers are likely to trade their shares after voluntary disclosures and gain benefits.

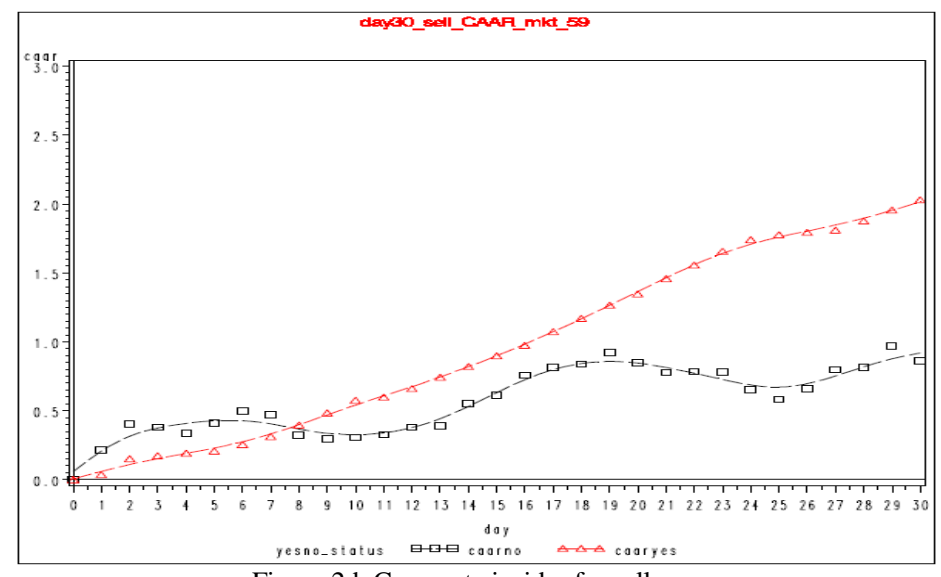

Figure 2d. Corporate insider for sell

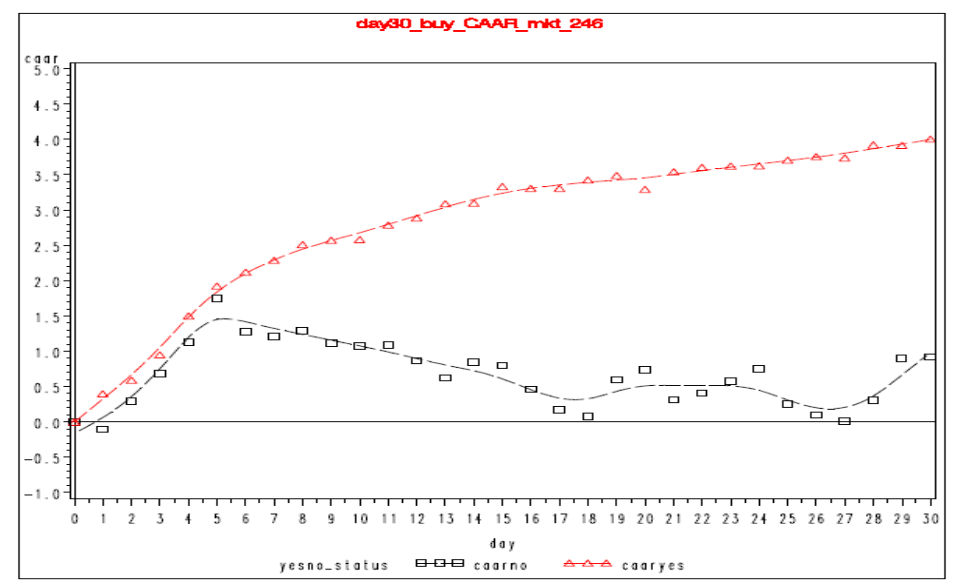

Figure 2e. Large shareholder for buy

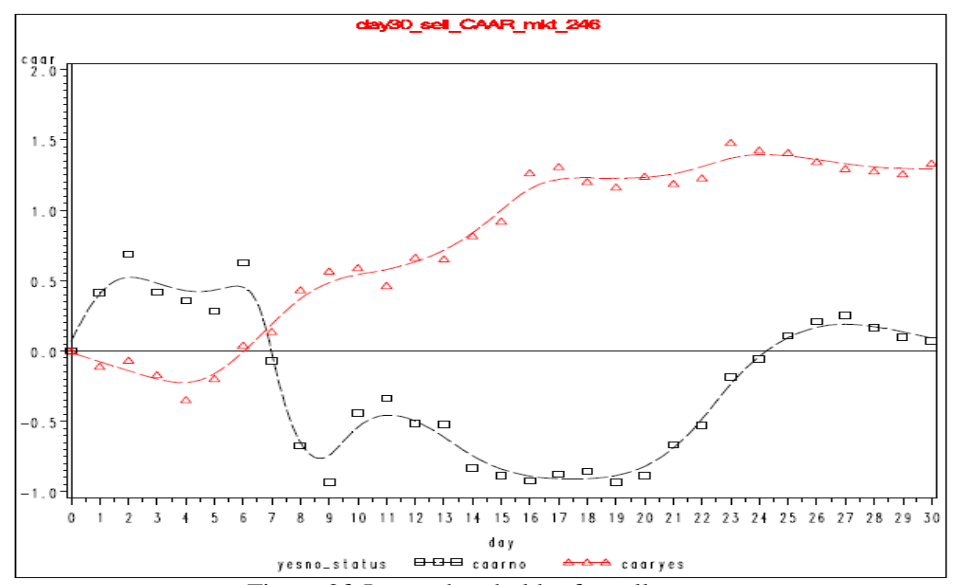

Figure 2f. Large shareholder for sell 
$H 2 b$ The abnormal returns are associated with the news contents. Insiders' buy (sell) shares before good (bad) news announcement gain large abnormal returns.

We test the news contents in detail along with insider transactions in $\mathrm{H} 2 \mathrm{~b}$. The right direction means insider trades by predicting the news contents. For example, they buy shares before good news and sell before bad news. The wrong direction defines as the contrary prediction. The neutral direction refers to insider transactions followed by neutral news. The statistical result is not provided due to limited space. For insider buy, the CAAR1,30 of right direction is significant and large. There exists significant differences between news directions for three insider groups at $1 \%$ level. Relating to insider sell, the three insider groups are significantly differences in news direction at $1 \%$ level. The wrong direction gives the largest CAAR1,30. The results also imply that insider sells before bad news and neutral news are likely to sell shares at the high price.

Trading before good news announcement shows significant abnormal return for both buy and sell. Only insider buy result is consistent with our hypothesis H2b. Insider buy prior to good news (the right direction) greatly impacts on prices. However, insider sell prior to good news (the wrong direction) also has large impact on prices. The possible explanation is that insider may sell shares under various reasons not only for profits but also for liquidity needs or portfolio diversification. In Cheng and Lo (2006) study, they find that insiders can time their stock buys around voluntary revelations for their personal gains.

Figure 3 show event day relative to insider trading by news contents. The graph shows the percentage cumulative average abnormal returns (CAAR) of insider trading. They are separated by the right direction (blue line), the wrong direction (green line) and the neutral direction (black line).

\section{v. Conclusion}

This paper investigates insider trading behavior and corporate news announcement for Thai listed firms in the SET. We analyze the sample of 490 firms with 29,752 insider transactions during 2000-2008. By using an event-study methodology, several important results are discovered.

First, the result of market reaction to insider buy is consistent with the previous studies. There exist significantly positive abnormal returns after insider buy. In contrast, the result of market reaction to insiders' sell is not negative which is inconsistent with the previous researches. This concludes that insiders have timing ability only for buy not for sell.

Second, insider sell before news tends to get large abnormal returns. After the analysis of news contents, the evidence shows that both insider buy and sell before good news announcement have significant impact on abnormal returns. Particularly, insider buy prior to good news (the right direction) greatly impacts on prices. This implies that insider trades exploit news contents only for buy but not for sell.
This study provides two empirical implications. Investors may consider the relation between insider trading activities and abnormal returns as one factor for their investment decision. Moreover, policy-makers should focus on the effect of corporate news disclosures on insider trading activities, so that they can develop rules and regulations to prevent someone from using inside information.

The limitation of research is that the sample study is legal insider trading. The future research should emphasize on illegal insider cases and compare the different performances with the legal. Another limitation is that our scope of study is insider trading common shares in SET. The further research can extend to the different securities or markets such as to study insider trading warrant in emerging markets.

\section{References}

[1] B. M. Barber and J. D Lyon, "Detecting long-run abnormal stock returns: the empirical power and specification of test statistics," Journal of Financial Economics, vol. 43, pp. 341-371, 1997.

[2] A. Betzer and E. Theissen, "Insider trading and corporate governance: the case of Germany," European Financial Management, vol. 61, pp. 402-429, 2009.

[3] S. J. Brown and J. B. Warner, "Using daily stock returns: the case of event studies," Journal of Financial Economics, vol. 14, pp.3-32, 1985.

[4] Q. Cheng and K. Lo, "Insider trading and voluntary disclosures," Journal of Accounting Research, vol. 44, pp. 815-848, 2006.

[5] J. P. Fidrmuc, M. Goergen, and L. Renneboog, "Insider trading, news releases, and ownership concentration," Journal of Finance, vol. 61, pp. 2931-2973, 2006.

[6] D. Givoly and D. Palmon, D., "Insider trading and the exploitation of inside information: some empirical evidence," Journal of Business, vol. 58, pp. 69-87, 1985.

[7] S. Huddart, B. Ke, and C. Shi, "Jeopardy, non-public information, and insider trading around SEC $10-\mathrm{K}$ and $10-\mathrm{Q}$ filings," Journal of Accounting and Economics, vol. 43, pp. 3-36, 2007.

[8] J. F. Jaffe, "Special information and insider trading", Journal of Business, vol. 47, pp. 410-428, 1974.

[9] A. R. Jabbour, A. Jalilvand, and J.A. Switzer, "Pre-bid price run-ups and insider trading activity: evidence from Canadian acquisitions," International Review of Financial Analysis, vol. 9, pp. 21-43, 2000.

[10] A. J. Keown and J. M. Pinkerton, "Merger announcements and insider trading activity: an empirical investigation," Journal of Finance, vol. 36, pp. 855-867, 1981.

[11] M. Koppel and I. Shtrimberg, "Good news or bad news? let the market decide," In AAAI Spring Symposium on Exploring Attitude and Affect in Text: Theories and Applications, 2004.

[12] J. Lakonishok and I Lee, "Are insider trades informative?," Review of Financial Studies, vol. 14, pp. 79-111, 2001.

About Author (s):

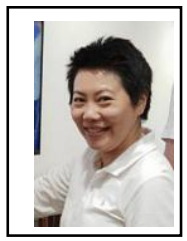

Insider trading: A trading of a company's stock by shareholders who may have access to non-public information about the company. It can be either legal or illegal conduct depending on the purpose and the time that insider makes the trade. 
Proc. of The Seventh Intl. Conf. on Advances in Social Science, Management and Human Behaviour - SMHB 2018. Copyright $\odot$ Institute of Research Engineers and Doctors, USA. All rights reserved.

ISBN: 978-1-63248-160-3 doi: 10.15224/978-1-63248-160-3-23

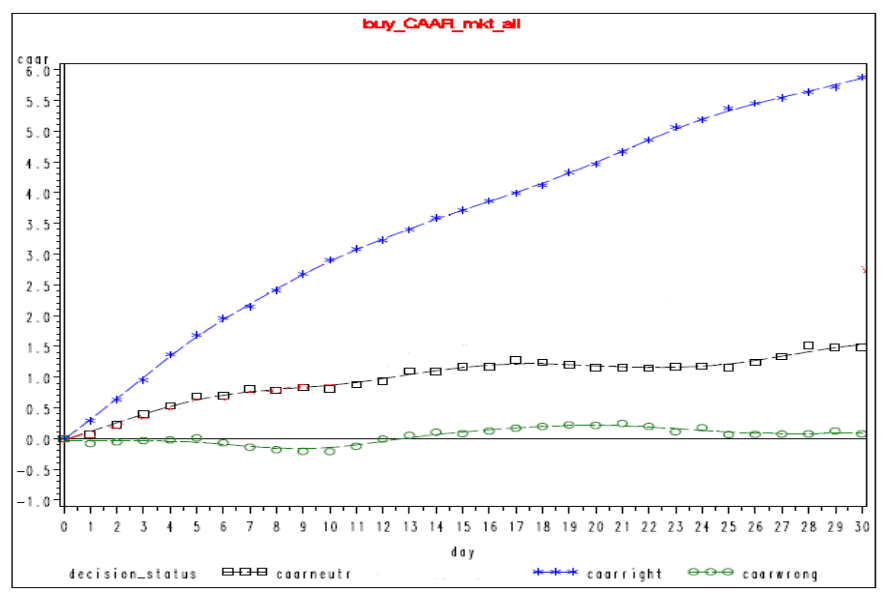

Figure 3a. All types of insider for buy

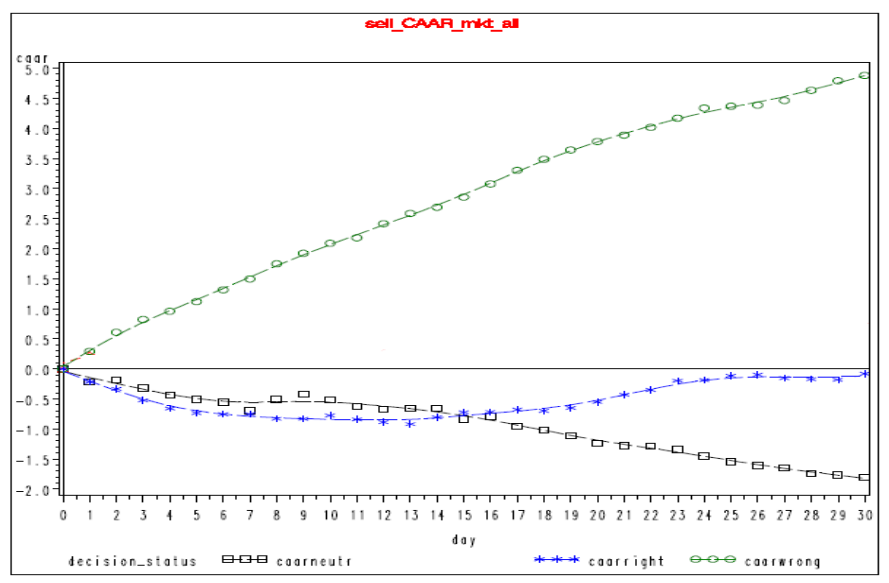

Figure 3a. All types of insider for sell

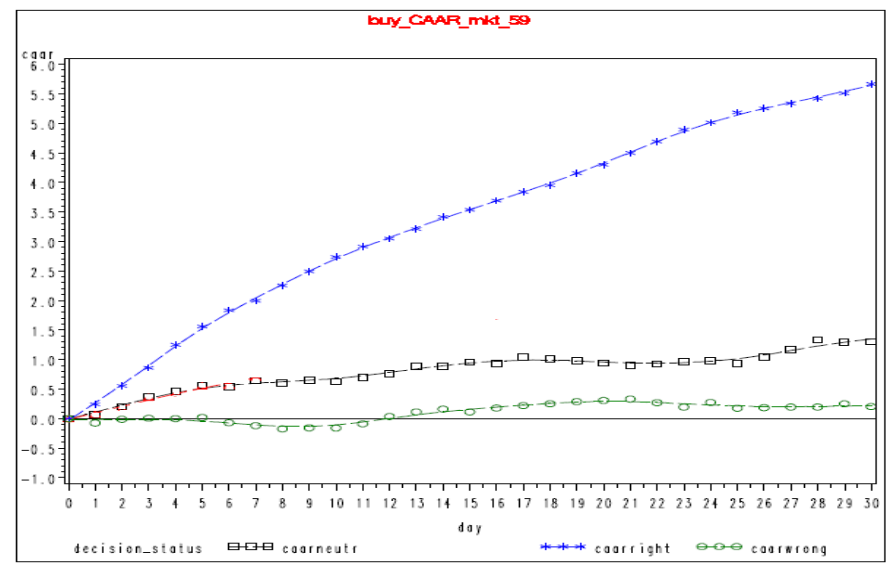

Figure 3c. Corporate insider for buy

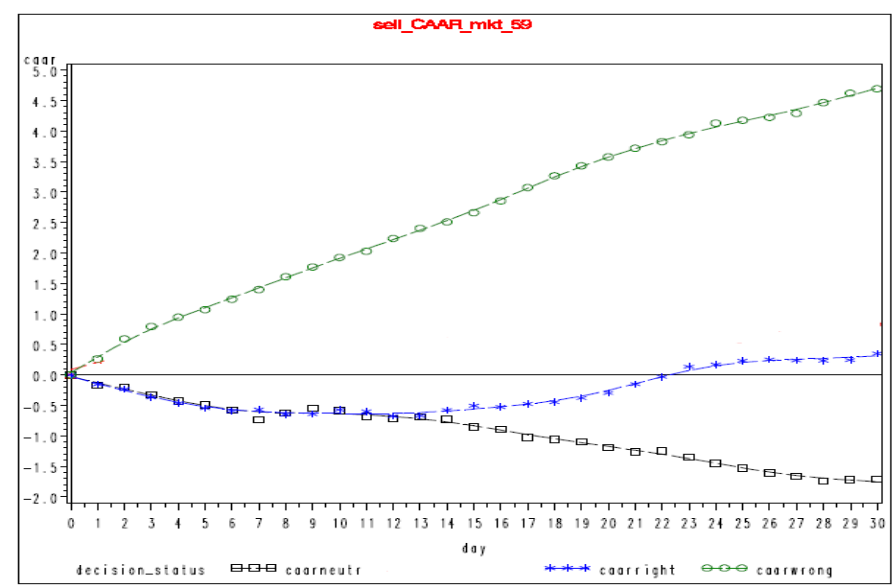

Figure 3d. Corporate insider for sell

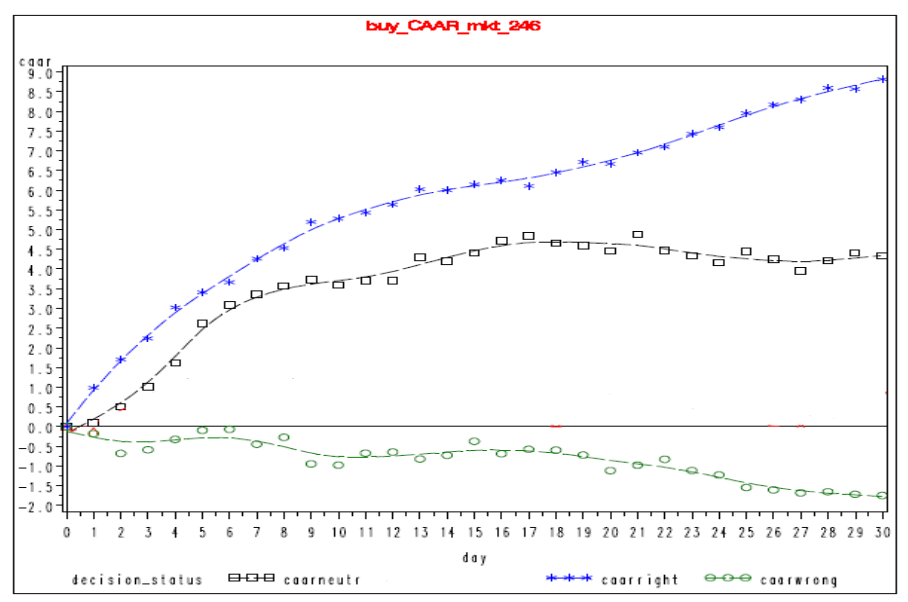

Figure 3e. Large shareholder for buy

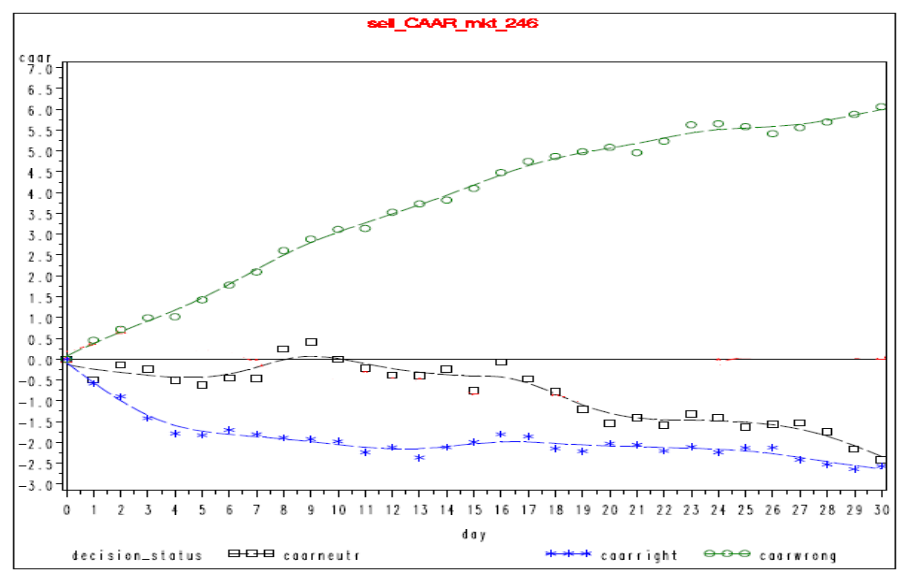

Figure 3f. Large shareholder for sell 